\title{
Development and Application of a Real-Time Reverse-Transcription PCR and Droplet Digital PCR Assays for the Direct Detection of Potato mop top virus in Soil
}

\author{
Binod Pandey, Ipsita Mallik, and Neil C. Gudmestad ${ }^{\dagger}$ \\ Department of Plant Pathology, North Dakota State University, Fargo, ND \\ Accepted for publication 19 August 2019.
}

\begin{abstract}
Potato mop top virus (PMTV) is a continuing threat to potato production throughout the world. It has the potential to persist in the soil for long periods in the sporosori of its vector Spongospora subterranea f. sp. subterranea, which is as an important source for PMTV infection and dissemination. In this study, we used real-time quantitative reversetranscription PCR (qRT-PCR) and reverse-transcription droplet digital PCR (RT-ddPCR) assays of the total RNA extracted directly from the soil to develop a simple, fast, and sensitive method to detect PMTV in soil samples using a specific primer with high efficiency despite a minimal amount of viral RNA. The designed primers are resilient in the presence of various PCR inhibitors in the soil when RNA is extracted. Both assays detected PMTV in all soil types used and supported the detection of $<10$ PMTV copies $\mu \mathrm{l}^{-1}$ in the RNA sample. With qRT-PCR, detection was linear, with amplification efficiencies ranging from 93.3 to $105.3 \%$ for silt loam, loamy sand, sand, and sandy loam in various experiments with
\end{abstract}

ABSTRACT
$R^{2}>0.99$. Furthermore, the RT-ddPCR assay also demonstrated a high degree of linearity $\left(R^{2}>0.99\right.$ and $\left.P<0.0001\right)$ with the RNA extracted from the soil samples representing different textures and physiochemical characteristics that were artificially spiked with infested $S$. subterranea f. sp. subterranea sporosori. Additionally, both assays successfully detected PMTV in different types of naturally infested soil with PMTV carrying S. subterranea f. sp. subterranea sporosori levels ranging from $6.2 \times 10^{2} \mathrm{~g}^{-1}$ to $1.2 \times 10^{6} \mathrm{~g}^{-1}$ in soils with $\mathrm{pH}$ ranging from 4.9 to 7.5 and organic matter ranging from 0.9 to $5.1 \%$, demonstrating the potential to detect PMTV in a wide variety of soils. To our knowledge, this is the first report of the development of real-time PCR and ddPCR methods for the direct detection of a soilborne virus in soil.

Keywords: soilborne virus, Potato mop top virus, quantitative reversetranscription PCR, RT-ddPCR
Potato mop top virus (PMTV) is an important potato pathogen of the genus Pomovirus of the family Virgaviridae (Adams et al. 2009). It is a tripartite, single-stranded RNA virus that contains three linear positive-sense single-stranded (ss) RNA molecules separately encapsulated in capsid protein (Savenkov et al. 2003; Scott et al. 1994). These RNAs are designated as RNA-Rep, RNA-CP, and RNA-TGB based on their encoded products (Adams et al. 2012). RNA-Rep is associated with virus replication and encodes components of RNA-dependent RNA polymerase (Savenkov et al. 1999). RNA-CP encodes capsid protein and a readthrough protein, and RNA-TGB encodes the triple gene block (TGB) of movement protein and a putative mini cysteine-rich $8 \mathrm{kDa}$ protein (Adams et al. 2012; Kashiwazaki et al. 1995).

PMTV causes potato mop top disease, which has been found in various potato-growing regions of the world (Abbas and Madadi 2016; Beuch et al. 2015; Garcia et al. 2013a; Santala et al. 2010; Xu et al. 2004). Disease symptoms may vary with environment and potato cultivars (Gil et al. 2016). In addition to the typical necrotic arcs and brown flecks in the tuber flesh, foliar symptoms such as reduction of internodes and yellow spots or V-shaped lesions, frequently referred to as chevrons, on the leaf caused by chlorosis may appear on the plant (Gil et al. 2016; Santala et al. 2010). The tuber necrosis caused by PMTV is responsible for the reduced quality of potato tubers, thus leading to significant economic losses (Mumford et al. 2000; Sandgren et al. 2002).

${ }^{\dagger}$ Corresponding author: N. C. Gudmestad; neil.gudmestad@ndsu.edu

Funding: This research was financially supported by USDA-NIFA-SCRI grant number 2014-51181-22373.

The author(s) declare no conflict of interest.

(C) 2020 The American Phytopathological Society
PMTV is transmitted by the soilborne plasmodiophorid Spongospora subterranea $\mathrm{f}$. sp subterranea, which causes powdery scab disease on susceptible potato cultivars (Bittara et al. 2016; Jones and Harrison 1972). PMTV has the potential to persist in the soil for long periods in resting spores or sporosori of its vector S. subterranea f. sp. subterranea, which is known to remain viable in the soil for years, even in the absence of the host crop (Calvert 1968; Falloon 2008; Jones and Harrison 1972; Merz and Falloon 2009). During favorable conditions, infested sporosori release PMTV-carrying zoospores with the ability to infect emerging tubers or roots and transmit the virus to the plant cell (Arif et al. 1995; Kirk 2008). Hence, the perseverance of PMTV in soil has an important role in virus transmission, and sensitive potato cultivars planted in soil with PMTV-carrying S. subterranea f. sp. subterranea sporosori are likely to be exposed to PMTV and, consequently, are at great risk for infection.

The ability to detect PMTV in the field soil could assist potato growers with avoiding planting susceptible potato cultivars in infested soil. Currently, detection of PMTV in the soil is based on bait plant bioassays using plants such as Nicotiana debneyi and $N$. benthamiana as hosts for virus propagation and detection (Arif et al. 2014; Davey 2009; Nakayama et al. 2010; Santala et al. 2010). The plant bioassay procedure is a tedious and time-consuming process because it takes several weeks to grow bait plants and conduct the bioassay. In addition, several steps involved in growing and testing bait plants maximize the potential errors that can lead to false-positive or false-negative results. Furthermore, the challenges of maintaining the favorable environmental conditions for $S$. subterranea f. sp. subterranea infection during the process to obtain reliable test results cannot be underestimated. Therefore, to better assess risks associated with PMTV on potato and to adopt a proper disease management strategy, it is important to develop a specific protocol for sensitive and rapid detection of PMTV in the 
soil. Technological progress in molecular procedures, including PCR-based methods, have provided a pathway for fast and accurate detection of PMTV in the soil, even with the possible presence of a minimum amount of viral RNA extracted from soil. This study investigated real-time reverse-transcription (RT) and digital droplet (dd) PCR of the total RNA extracted directly from the soil to develop a simple, fast, and sensitive method to detect PMTV.

\section{MATERIALS AND METHODS}

Collection and preparation of soil samples. Soil samples obtained from PMTV-infested and noninfested potato fields located in North Dakota, Maine, Idaho, Colorado, and Washington were used for protocol development and assessment. Soil subsamples were submitted to the soil testing laboratory at North Dakota State University to determine texture, $\mathrm{pH}$, and organic matter (OM) content. The remainder of the soil samples were dried at ambient temperature, followed by grinding of each soil individually to a fine powder using a flail-type soil pulverizer (Agvise, ND). The pulverizer was dusted, sprayed, and wiped with alcohol between grinding the soil samples to avoid cross-contamination. The ground soil samples were then stored in a walk-in cold room $\left(4^{\circ} \mathrm{C}\right)$ until they were used. The presence of $S$. subterranea $\mathrm{f}$. sp. subterranea sporosori in naturally infested soil was determined by real-time quantitative PCR of DNA extracted from the soil (Mallik et al. 2019).

To spike the soil with PMTV-infested $S$. subterranea f. sp. subterranea sporosori, $S$. subterranea $\mathrm{f}$. sp. subterranea-free soil samples were used. These samples were sterilized by autoclaving twice at $121^{\circ} \mathrm{C}$ for $60 \mathrm{~min}$ before storing at $4^{\circ} \mathrm{C}$. Sporosori of $S$. subterranea f. sp. subterranea were harvested from the surface of S. subterranea f. sp. subterranea and PMTV-infected potato tubers by scraping with a scalpel, followed by grinding and sequential sieving with 40 to 150 mesh screens. Sporosori were suspended in nuclease-free water and counted using a hemocytometer. The sporosori concentrations of 20,000 sporosori $\mathrm{ml}^{-1}, 10,000$ sporosori $\mathrm{ml}^{-1}, 5000$ sporosori $\mathrm{ml}^{-1}, 1000$ sporosori $\mathrm{ml}^{-1}, 500$ sporosori $\mathrm{ml}^{-1}$, and 100 sporosori $\mathrm{ml}^{-1}$ were prepared by serial dilution. These dilutions of sporosori were added to $1-\mathrm{g}$ aliquots of sterilized soil and then incubated at ambient temperature for 5 to 7 days.

Extraction and refinement of total RNA. Total RNA was extracted from artificially PMTV-infested soil as well as naturally infested soil samples using a soil total RNA purification kit (Norgen BioteK, ON, Canada) according to the manufacturer's instructions with a supplementary DNase digestion step using RNAase-free DNase I (Norgen BioteK, ON, Canada and Qiagen, Valencia, CA) to remove contaminating genomic DNA. To improve the quality of RNA for downstream applications, extracted total RNA from two subsamples of $0.4 \mathrm{~g}$ of soil were pooled together and further purified using RNeasy PowerClean Pro Cleanup kit (Qiagen, CA).

The integrity of RNA was confirmed by the standard electrophoresis technique. Additionally, RNA quality and quantity were evaluated using a NanoDrop 2000c spectrophotometer. Total RNA was immediately stored at $-80^{\circ} \mathrm{C}$ in the ultra-deep freezer for further procedures.

Primers and probes. Three sets of primers and probes targeting the PMTV coat protein-readthrough protein gene were designed using sequences obtained from the NCBI GenBank database via the GenScript real-time PCR (TaqMan) primer design tool (Table 1). In addition, a previously described primer-probe set (PMTV-1948F/PMTV-2017R/PMTV-1970) (Mumford et al. 2000) was assessed and used to make comparisons between the newly designed primer-probe sets. The goal was to identify sensitive and specific primers with high efficiency that were capable of detecting a small amount of viral RNA in the presence of various PCR inhibitors in soil-extracted RNA. First, putative amplicon sequences anticipated from each potential primer-probe set were compared with the available sequences in the NCBI GenBank database using the BLAST program to confirm their specificity. Then, primer-probe sets were tested with quantitative reversetranscription (qRT) PCR (qRT-PCR) using RNA extracted from PMTV-infested $S$. subterranea f. sp. subterranea sporosori adjusted to $\approx 1 \times 10^{3}$ copies $\mu \mathrm{l}^{-1}$ viral target sandy loam soil artificially spiked with $S$. subterranea $\mathrm{f}$. sp. subterranea sporosori at the rate of

TABLE 1. Primers and probes for Potato mop top virus (PMTV) detection and their preliminary test results

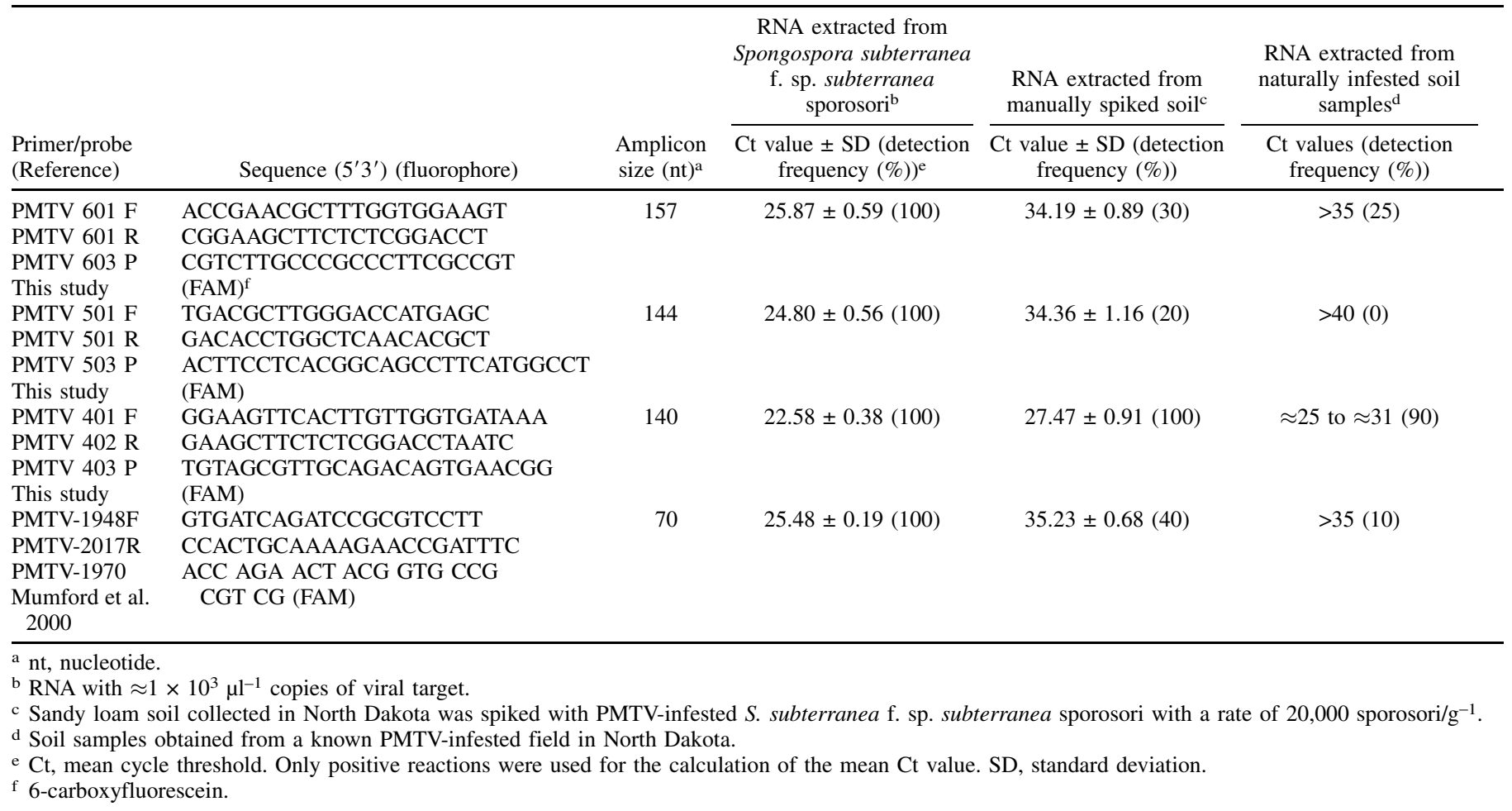


20,000 sporosori $\mathrm{g}^{-1}$ and soil samples obtained from a known PMTV-infested field in North Dakota. Additionally, selected PCR products were cleaned with the QIAquick PCR purification Kit (Qiagen) and subjected to Sanger sequencing (Retrogen, Inc., San Diego, CA) for further validation of amplicon sequences. Based on the initial results, the primer-probe set with the most reliable and reproducible detection, as measured and determined by the lowest cycle threshold $(\mathrm{Ct})$ or quantitation cycle $(\mathrm{Cq})$ value, was selected for further PMTV detection method development.

Real-time quantitative reverse-transcription PCR. The newly designed primer-probe set PMTV 401F/PMTV 402R/ PMTV 403P (Table 1) selected using the previous step was used for further qRT-PCR assays. One-tube, one-step qRT-PCR was performed in $20 \mu \mathrm{l}$ of reaction mix using the GoTaq Probe 1-step RT-PCR system (Promega, USA). The qRT-PCR reaction mixture contained $10 \mu \mathrm{l}$ of GoTaq Probe qPCR master Mix $(2 \times), 0.4 \mu \mathrm{l}$ of GoScript RT Mix for 1-step qRT-PCR (50x), $1 \mu \mathrm{l}$ of each forward and reverse primer at a concentration of $900 \mathrm{nM}, 0.5 \mu \mathrm{l}$ of a probe at a concentration of $250 \mathrm{nM}, 4 \mu \mathrm{l}$ of RNA template, and nuclease-free water to $20 \mu \mathrm{l}$. qRT-PCR was performed using a thermal cycler (CFX96 Real-Time System; Bio-Rad) to amplify DNA fragments using the following cyclic condition: reverse transcription at $45^{\circ} \mathrm{C}$ for 15 min followed by polymerase activation and DNA denaturation for $2 \mathrm{~min}$ at $95^{\circ} \mathrm{C}$; and 50 cycles of amplification with each cycle at $95^{\circ} \mathrm{C}$ for $10 \mathrm{~s}$ and $30 \mathrm{~s}$ for $60.4^{\circ} \mathrm{C}$.

RNA extracted from PMTV-infested $S$. subterranea f. sp. subterranea sporosori was used as a positive control. To prepare standard curves, a 10-fold dilution series of RNA extracted from PMTV-infested S. subterranea f. sp. subterranea sporosori was used. Viral copies of standards were determined by using the PMTV genesig Standard Kit (Primerdesign, UK) according to the manufacturer's instructions. In brief, the kit contains a template with a known concentration of PMTV coat protein-readthrough protein gene that can be used to generate a standard curve to estimate the copy number in the RNA extracted from PMTV-infested S. subterranea f. sp. subterranea sporosori. First, a real-time RT-PCR protocol and the standard curve developed with the known concentration of coat protein-readthrough protein gene were used to determine the number of coat protein-readthrough protein genes in RNA extracted from the PMTV-infested S. subterranea $\mathrm{f}$. sp. subterranea sporosori. Then, a 10-fold serial dilution of quantified RNA was used as a standard curve for the development of assays for the direct detection of PMTV in soil. Viral copy numbers used for constructing standard curves ranged from $\approx 1$ to $1 \times 10^{4} \mu \mathrm{l}^{-1}$. The standard curve and $\mathrm{Ct}$ values of qRTPCR assays were determined using Bio-Rad CFX Manager 3.1 software (Bio-Rad, CA). Three independent qRT-PCR assays were conducted for each soil sample. All statistical analyses related to qRT-PCR data were conducted with Minitab 18 statistical software (State College, PA).

Reverse-transcription droplet digital PCR assay. The RTddPCR assay was performed after optimizing the qRT-PCR. The one-step RT-ddPCR advanced kit for probes (Bio-Rad, CA) using the identical primer-probe set selected for the qRT-PCR was used for the RT-ddPCR. Each reaction mixture $(20 \mu \mathrm{l})$ contained $5 \mu \mathrm{l}$ of supermix, $2 \mu \mathrm{l}$ of reverse transcription, $1 \mu \mathrm{l}$ of $300 \mathrm{mM}$ DTT, $1 \mu \mathrm{l}$ $(450 \mathrm{nM})$ of each forward and reverse primer, $0.5 \mu \mathrm{l}(250 \mathrm{nM})$ of probe, $4 \mu \mathrm{l}$ of RNA template, and nuclease-free water to $20 \mu \mathrm{l}$. Each designated well of a DG8 cartridge (Bio-Rad) assembled with the DG8 cartridge holder was manually loaded with $20 \mu \mathrm{l}$ of reaction mixture and $70 \mu \mathrm{l}$ of QX200 droplet generation oil (Bio-Rad) and placed in the QX 200 droplet generator for droplet creation. Generated droplets (40 $\mu$ l each) were transferred to a 96-well PCR plate and sealed with a heat seal foil using PX1 PCR plate sealer (Bio-Rad). The PCR assay was performed on a S1000 thermal cycler. The cyclic and temperature conditions used for the PCR assay were as follows: reverse transcription at $45^{\circ} \mathrm{C}$ for $60 \mathrm{~min}$; enzyme activation for $10 \mathrm{~min}$ at $95^{\circ} \mathrm{C} ; 40$ cycles of $30 \mathrm{~s}$ at $95^{\circ} \mathrm{C}$ for denaturation, followed by $1 \mathrm{~min}$ at $60.4^{\circ} \mathrm{C}$ (ramp speed of $2.5 \mathrm{C} / \mathrm{s}$ ) for annealing/extension; and enzyme deactivation at $98^{\circ} \mathrm{C}$ for $10 \mathrm{~min}$, followed by cooling at $4^{\circ} \mathrm{C}$. The PCR assay was analyzed with a QX200 droplet reader and QuantaSoft Analysis Pro (BioRad, CA). Three independent RT-ddPCR assays were conducted for each soil sample. Linear regression curves were calculated by plotting virus copy number concentrations determined by RTddPCR and expected values of serially diluted RNA extracted from PMTV-infested $S$. subterranea f. sp. subterranea sporosori against each other. All statistical analyses were conducted with Minitab 18 statistical software (State College, PA).

\section{RESULTS}

Primer-probe selection. Newly designed primer-probe sets PMTV 401F/PMTV 402R/PMTV 403P, PMTV 501F/PMTV502R/ PMTV503P, and PMTV601F/PMTV602R/PMTV603P were found to amplify single products of 140-nucleotide (nt), 144-nt, and 157-nt fragments of PMTV coat protein-readthrough protein genes, respectively (Table 1). Sequencing of amplicons followed by database searches also confirmed their similarity to the targeted sequence. Similarly, primer-probe set PMTV-1948F/PMTV-2017R/PMTV1970 (Mumford et al. 2000) was also found to amplify a single product of a 70-nt fragment of PMTV coat protein gene. During initial experiments, all four primer-probe sets were able to detect PMTV in the RNA extracted from PMTV-infested $S$. subterranea f. sp. subterranea sporosori with $\approx 1 \times 10^{3} \mu \mathrm{l}^{-1}$ copies of viral target. However, the $\mathrm{Ct}$ value generated by the primer-probe set PMTV 401F/PMTV 402R/PMTV 403P was substantially lower than that of PMTV501F/PMTV502R/PMTV503P, PMTV601F/PMTV602R/ PMTV603P, and PMTV-1948F/PMTV-2017R/PMTV-1970. In addition, PMTV 401F/PMTV 402R/PMTV 403P yielded the most reliable detection with the lowest $\mathrm{Ct}$ value and $100 \%$ detection frequency when tested with RNA extracted from artificially spiked soil using PMTV-infested $S$. subterranea f. sp. subterranea sporosori at a rate of 20,000 sporosori $\mathrm{g}^{-1}$. Furthermore, it detected PMTV in $90 \%$ of the samples collected from the PMTV-infested field in North Dakota (Table 1). Using these data, the primer-probe set PMTV 401F/PMTV 402R/PMTV 403P was determined to be superior to a published PMTV PCR protocol (Mumford et al. 2000); therefore, the other newly designed primer-probe set was selected for further development (Table 1).

qRT-PCR. A 10-fold dilution series of RNA extracted from PMTV-infested S. subterranea f. sp. subterranea sporosori was used in standard curve constructions. To achieve this, the copy number of the PMTV target (RNA-CP) in extracted RNA was determined and then adjusted to $1 \times 10^{4} \mu \mathrm{l}^{-1}$. Subsequently, serial 10 -fold dilutions of RNA templates from $1 \times 10^{4}$ to $1 \mu \mathrm{l}^{-1}$ copies were used to determine the efficiency and linearity of qRT-PCR. In standard curves obtained from various experiments, amplification efficiency ranged from 93.7 to $97.6 \%$, with $R^{2}>0.99$ indicating that this assay is reliable for the detection and quantification of PMTV.

The detection limit of the assay was determined using a 10-fold dilution series $\left(\approx 1 \times 10^{3} \mu \mathrm{l}^{-1}\right.$ to $0.1 \mu \mathrm{l}^{-1}$ target copies $)$ of RNA extracted from the artificially spiked soil samples representing different textures and physiochemical characteristics. Soils were spiked with $\approx 1 \times 10^{6} \mathrm{PMTV}$-infested $S$. subterranea $\mathrm{f}$. sp. subterranea sporosori $\mathrm{g}^{-1}$ and extracts diluted accordingly. PMTV was detected at PMTV levels $<10$ copies/ $\mu 1^{-1}$ in the RNA samples of all soil types. In addition, detections were linear over five $\log 10$ steps with amplification efficiency of 93.3, 101.8, 95.6, and 105.3\%, respectively, for the silt loam ( $\mathrm{pH} 5.8$ and OM 5.0\%), loamy sand ( $\mathrm{pH}$ 7.5 and $\mathrm{OM} \mathrm{1.4 \% ),} \mathrm{sand} \mathrm{(pH} 6.7$ and $\mathrm{OM} \mathrm{0.9 \% ),} \mathrm{and} \mathrm{sandy} \mathrm{loam}$ (pH4.9 and OM 3.5\%), with $R^{2}>0.99$ demonstrating that this assay is reproducible for use in soils with different textures and physiochemical characteristics (Fig. 1). The lower detection limit using RNA extracted from composite soil samples spiked with PMTV-infested $S$. subterranea $\mathrm{f}$. sp. subterranea was determined as low as 500 sporosori $\mathrm{g}^{-1} 40 \%$ of the time (Table 2). 
RT-ddPCR. A 10-fold dilution series of RNA extracted from PMTV-infested S. subterranea f. sp. subterranea sporosori with viral copies ranging from $1 \times 10^{4}$ to $1 \mu \mathrm{l}^{-1}$ was used to evaluate RT-ddPCR performance and for comparisons with qRT-PCR.
Standard curves generated for the qRT-PCR showed amplification efficiency of $95.5 \%$, with $R^{2}=0.999$ (Fig. 2A). As with qRT-PCR, in RT-ddPCR assays, predicted target amounts and ddPCR-measured values determined a high degree of linearity
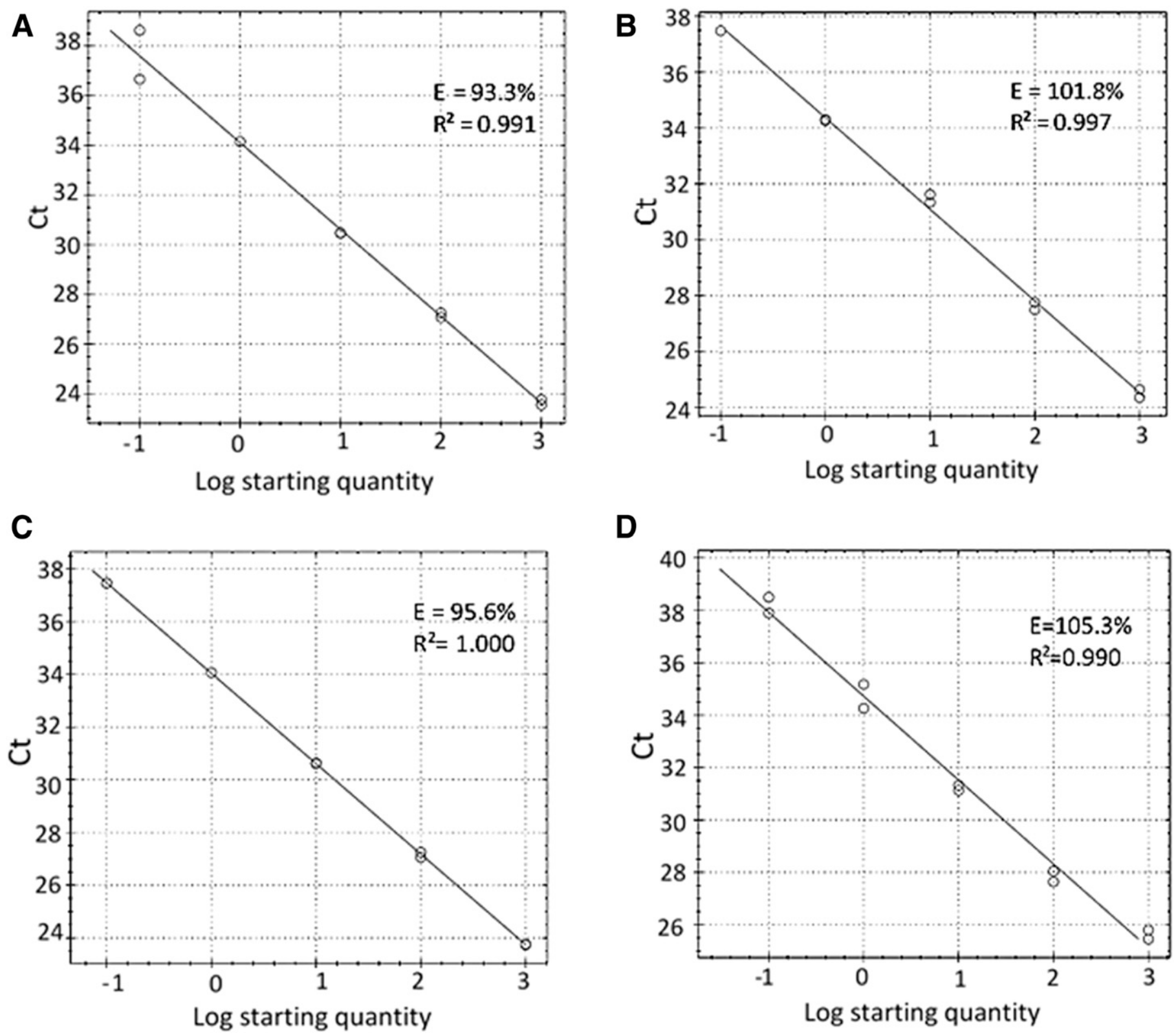

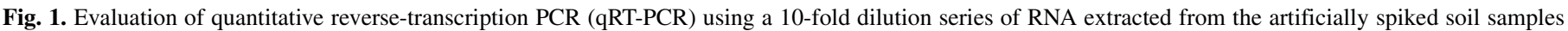

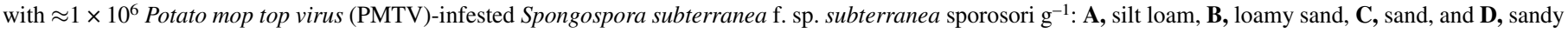
loam.

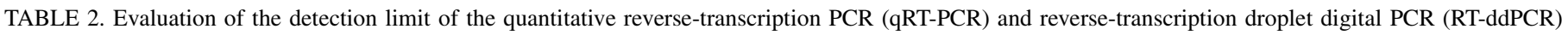
assays based on Potato mop top virus (PMTV)-infested vector in the soil

\begin{tabular}{|c|c|c|c|c|c|c|}
\hline $\begin{array}{l}\text { PMTV infested Spongospora } \\
\text { subterranea } \mathrm{f} \text {. sp. subterranea } \\
\text { sporosori } \mathrm{g}^{-1} \text { soil }\end{array}$ & $\begin{array}{l}\text { qRT-PCR Ct } \\
\text { value } \pm \mathrm{SD}^{\mathrm{a}}\end{array}$ & $\mathrm{CV}(\%)^{\mathrm{b}}$ & $\begin{array}{c}\text { Detection } \\
\text { frequency }(\%)\end{array}$ & $\begin{array}{l}\text { RT-ddPCR detected } \\
\text { concentration } \\
\text { copies } \mu \mathrm{l}^{-1} \pm \mathrm{SD}\end{array}$ & $\mathrm{CV}(\%)$ & $\begin{array}{c}\text { Detection } \\
\text { frequency }(\%)\end{array}$ \\
\hline 20,000 & $27.10 \pm 0.54$ & 2.01 & 100 & $159.00 \pm 7.62$ & 4.79 & 100 \\
\hline 10,000 & $28.77 \pm 0.83$ & 2.88 & 100 & $44.97 \pm 5.00$ & 11.12 & 100 \\
\hline 5000 & $29.99 \pm 0.41$ & 1.36 & 100 & $9.97 \pm 0.05$ & 0.52 & 100 \\
\hline 1000 & $31.48 \pm 0.29$ & 0.92 & 80 & $5.03 \pm 0.41$ & 8.22 & 100 \\
\hline 500 & $31.66 \pm 0.37$ & 1.66 & 40 & $2.61 \pm 0.39$ & 15.08 & 80 \\
\hline 100 & Not detected & & 0 & Not detected & & 0 \\
\hline
\end{tabular}

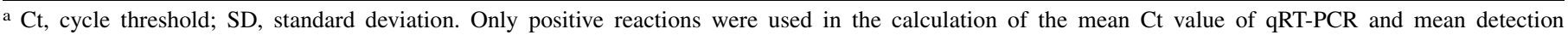
concentration $\mu \mathrm{l}^{-1}$ for RT-ddPCR.

b $\mathrm{CV}$, coefficient of variance. 
( $R^{2}=1$ and $P<0.0001$ ), demonstrating that the RT-ddPCR assay can detect and quantify PMTV with a high degree of resolution (Fig. 2B).

The RNA extracted from the soil samples spiked with $\approx 1 \times 10^{6}$ PMTV-infested S. subterranea f. sp. subterranea sporosori $\mathrm{g}^{-1}$, representing silt loam, loamy sand, sand, and sandy loam, also exhibited a high degree of linearity in RT-ddPCR assays over the
10 -fold dilution series. Among all soil types, $R^{2}$ values varied from 0.9924 to 1.0 and were statistically significant $(P<0.0001)$ (Fig. 3$)$. The ddPCR assay was able to detect PMTV from targets as low as $0.30,0.59,0.25$, and 0.22 copies $/ \mu 1^{-1}$ from RNA extracted from artificially spiked silt loam, loamy sand, sand, and sandy loam, respectively (Fig. 3). In addition, the detection limit based on the PMTV-infested vector in the soil was determined to be as low as 500

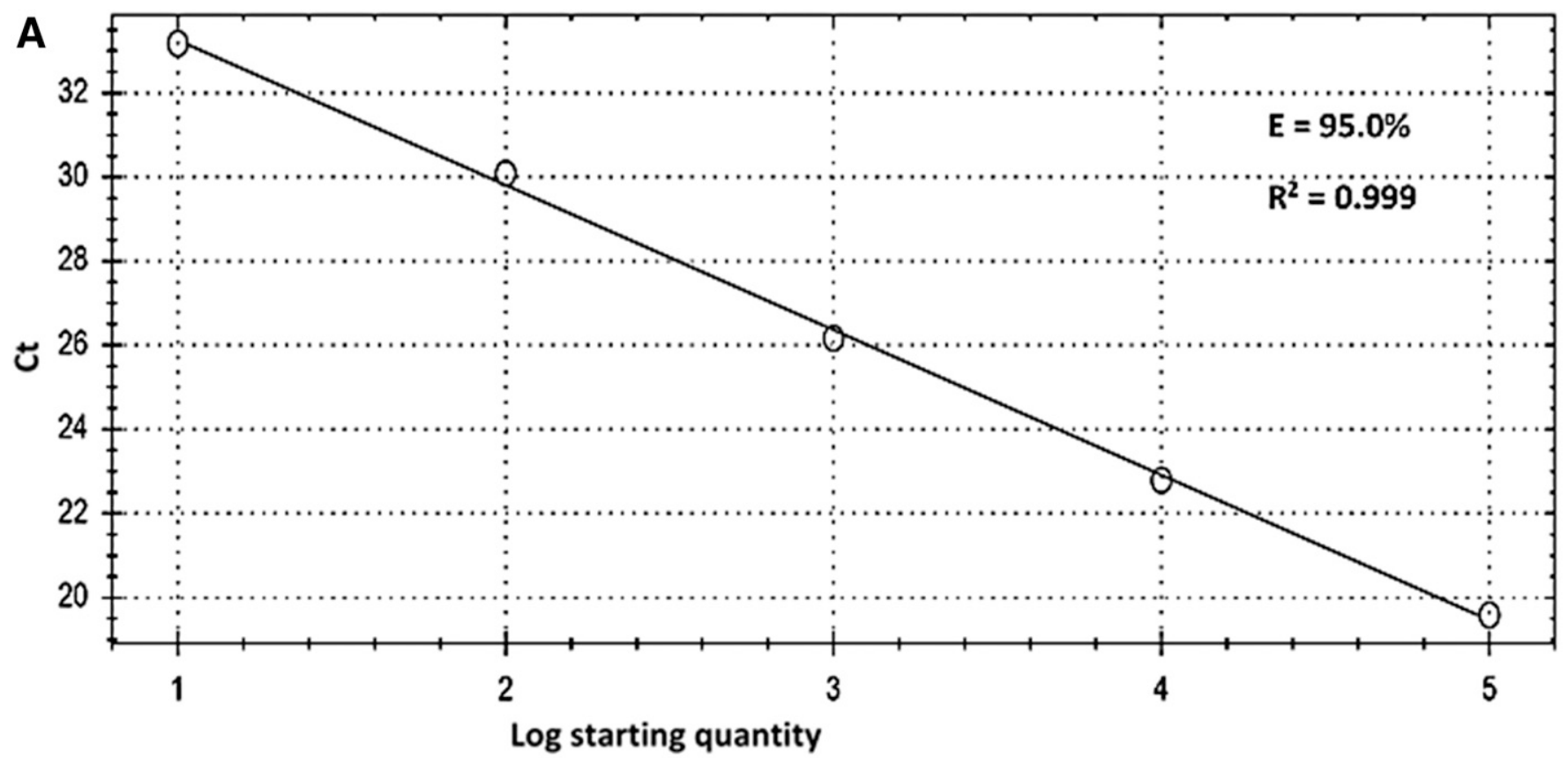

B

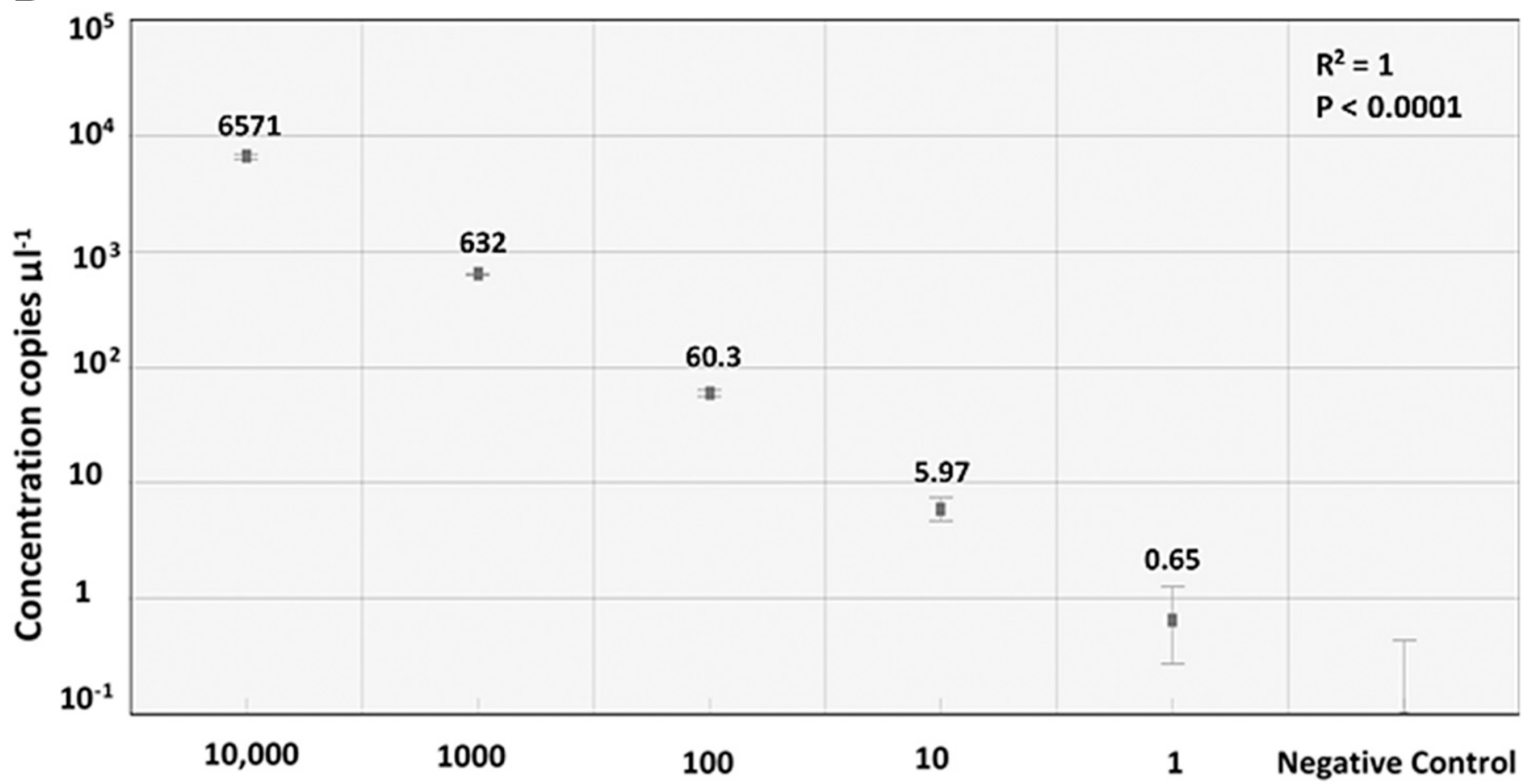

\section{Starting concentration copies $\mu^{-1}$}

Fig. 2. A, Standard curve of quantitative reverse-transcription PCR (qRT-PCR) and B, linear quantitative range of reverse-transcription droplet digital PCR (RTddPCR) constructed using 10-fold serial dilutions of RNA with target copies ranging from $1 \times 10^{4}$ to $1 \mu \mathrm{l}^{-1}$ extracted from the Potato mop top virus (PMTV)infested Spongospora subterranea f. sp. subterranea sporosori. 
S. subterranea $\mathrm{f}$. sp. subterranea sporosori $\mathrm{g}^{-1} 80 \%$ of the time (Table 2).

Evaluation of qRT-PCR and RT-ddPCR assays with field-collected soil samples. The qRT-PCR and RT- ddPCR assays were evaluated using selected naturally infested and noninfested soil samples collected from Maine, Indiana, North Dakota, Washington, and Colorado. The assayed soil samples had considerable variations in textures, $\mathrm{pH}$ (4.9 to 7.9 ), OM content ( 0.9 to $5.1 \%$ ), and amount of $S$. subterranea $\mathrm{f}$. sp. subterranea sporosori (Table 3). The qRT-PCR and RT-ddPCR assays effectively detected PMTV in naturally infested silt loam, loamy sand, sand, and sandy loam. In addition, both assays successfully detected PMTV in these naturally infested soils, with $S$. subterranea f. sp. subterranea sporosori levels ranging from $6.2 \times 10^{2}$ to $1.2 \times 10^{6} \mathrm{~g}^{-1}$ (Table 3). Results from these assays clearly demonstrated the potential to detect PMTV from a wide variation of soil types using either qRT-PCR or RT-ddPCR methods.

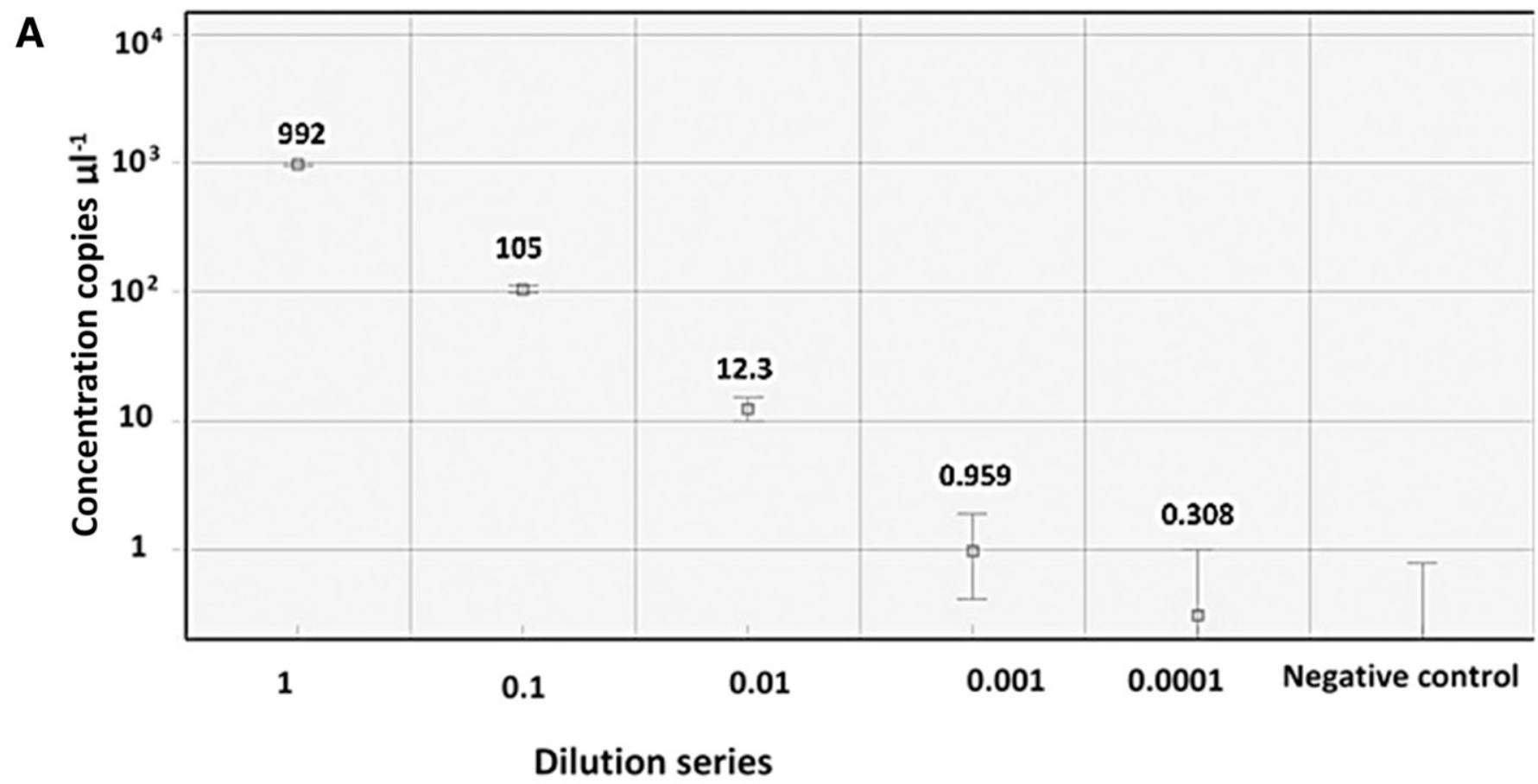

B

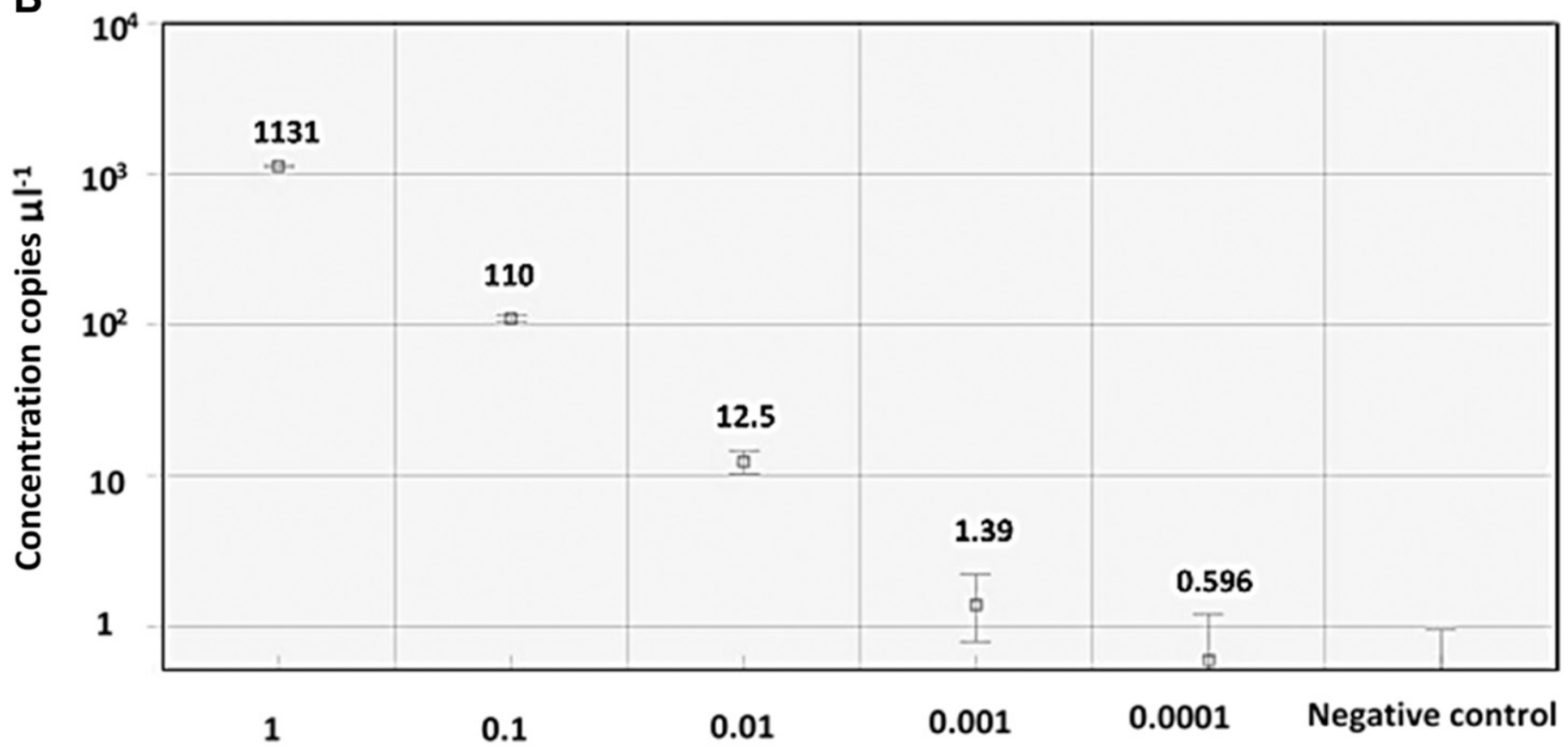

Dilution series

(Continued)

Fig. 3. Linear quantitative range of reverse-transcription droplet digital PCR (RT-ddPCR) assay constructed using RNA extracted from the artificially spiked soil samples with $\approx 1 \times 10^{6}$ Potato mop top virus (PMTV)-infested Spongospora subterranea $\mathrm{f}$. sp. subterranea sporosori $\mathrm{g}^{-1}$ representing $\mathbf{A}$, silt loam $\left(R^{2}=1\right.$ and $P<$ $0.0001)$, B, loamy sand $\left(R^{2}=1\right.$ and $\left.P<0.0001\right)$, C, sand $\left(R^{2}=1\right.$ and $\left.P<0.0001\right)$, and $\mathbf{D}$, sandy loam $\left(R^{2}=0.9924\right.$ and $\left.P<0.0001\right)$. 


\section{DISCUSSION}

Detection of PMTV directly from soil has been a challenge that has hindered the effective management of this potato pathogen for some time. Prior to the studies performed and reported here, PMTV could only be effectively detected using bioassay bait plants, such as Nicotiana debneyi, capable of being colonized by S. subterranea $\mathrm{f}$. sp. subterranea when grown in infested soil (Arif et al. 2014; Davey 2009; Nakayama et al. 2010). Rapid direct detection of PMTV in naturally infested field soil can assist in the implementation of appropriate disease management strategies. Although various methods of PMTV detection and identification have been described (Garcia et al. 2013b; Nakayama et al. 2010; Ryazantsev and Zavriev 2009; Santala et al. 2010; Sokmen et al. 1998), none of these methods allows direct detection in the soil. This study offers new qRTPCR and RT-ddPCR based assays as effective alternatives for directly detecting PMTV in infested soil.

Although a number of PCR assays have been developed to detect soilborne plant viruses, many have been used only to detect and quantify these viruses in plant tissue, but not in soil (Deb and Anderson 2008; Meunier et al. 2003; Ratti et al. 2004). There is a dearth of published information regarding the detection of soilborne

Fig. 3. (Continued from previous page)

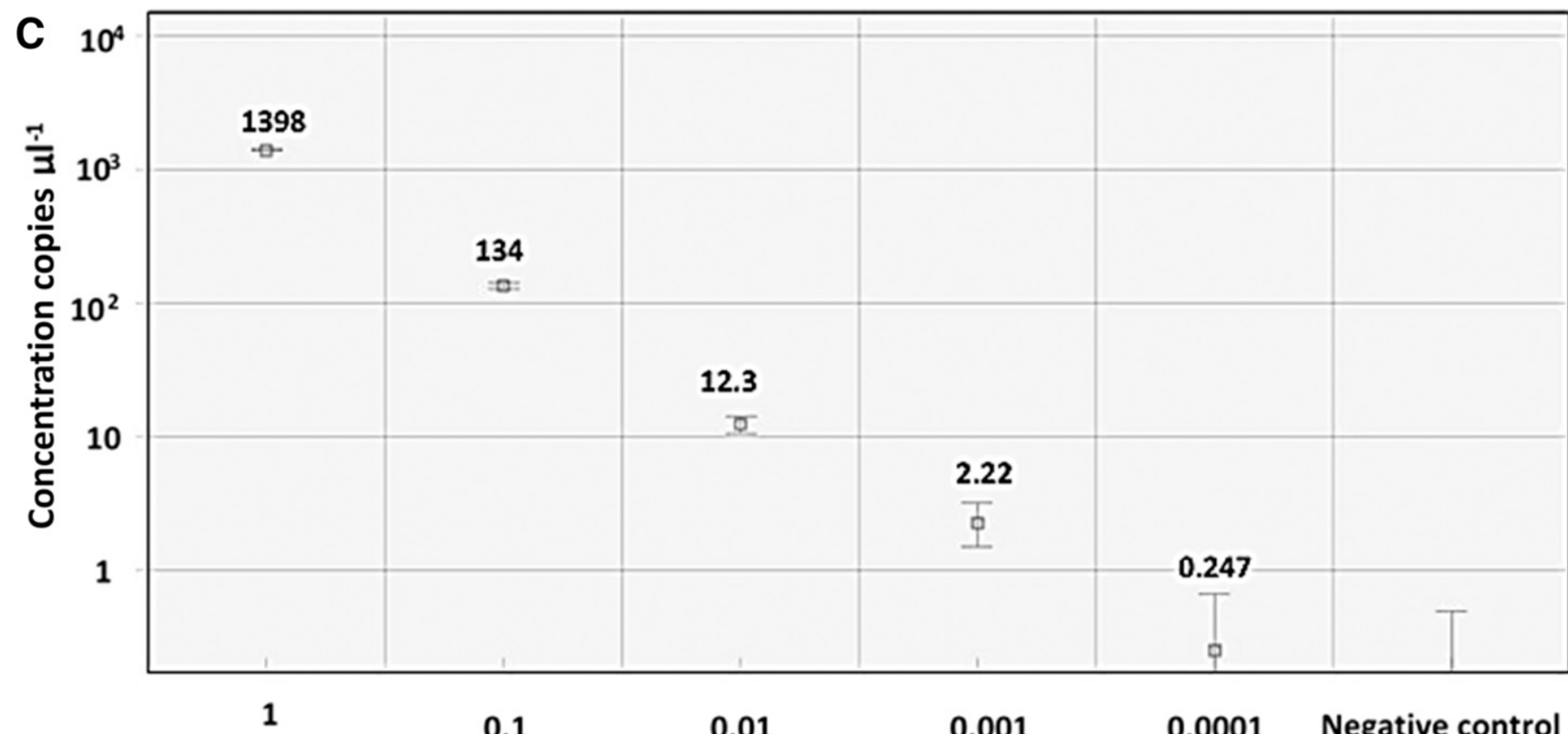

Dilution series

D

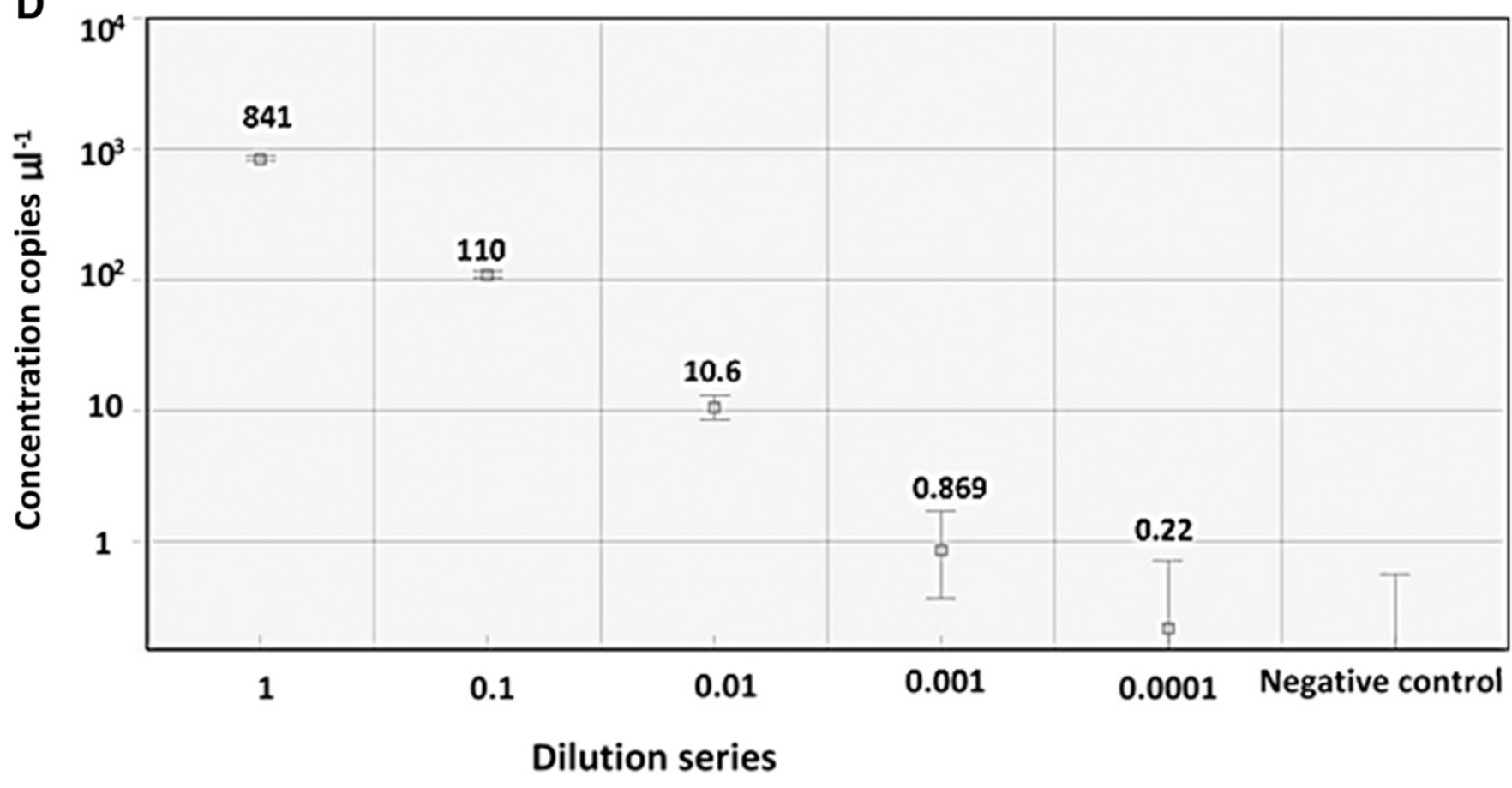


plant viruses directly from the soil. A previous study reported the conventional PCR-based method for detecting Beet necrotic yellow vein virus using total nucleic acid extracted from the naturally infested soil (Ghorbani et al. 2013). Yet, to the best of our knowledge, this study is the first to present assays based on qRT-PCR and RT-ddPCR to detect a soilborne plant virus directly from RNA extracted from the naturally infested soil. This study not only has the potential to replace the tedious and time-consuming bait plant bioassay method of PMTV detection but also may allow for the evaluation of the possibility of developing similar detection methods for other soilborne plant viruses.

Extraction of total RNA from the soil was a key step in the development of the assays based on qRT-PCR and RT-ddPCR. The total RNA extraction method used for this study was based on the commercially available kit, which successfully recovered total RNA from both the artificially inoculated and the naturally infested soil. Soil samples can be very diverse and complex in their $\mathrm{pH}, \mathrm{OM}$ content, and texture; therefore, any RNA extraction procedure and PCR assay developed to detect a soilborne virus such as PMTV must be robust to increase its utility across a variable environment such as soil. In addition to the variable RNA yield, the presence of inhibitory compounds may affect the downstream applications of RNA in the RT-PCR. Hence, a further purification step was conducted to improve the quality of the RNA whenever needed. Generally, the total RNA extraction and cleaning procedures applied here were suitable for maintaining the integrity of PMTV genomes in extracts. Additionally, the single-tube, one-step PCR method decreased the number of steps involved, thereby reducing the risk of errors that can lead to false-positive or false-negative results.

Primers and probes for qRT-PCR and RT-ddPCR were designed and evaluated using the stretch of nucleotides located in the coat protein-readthrough protein gene identified as conserved in PMTV isolates from the United States (Crosslin 2011; David et al. 2010; Kaur et al. 2016; Lambert et al. 2003; Mallik and Gudmestad 2015; Ramesh et al. 2014; Xu et al. 2004). The coat protein-readthrough protein gene was chosen because it is associated with vector acquisition and transmission (Adams et al. 2001; Reavy et al. 1998); therefore, it is more likely to be detected in the vector-infested soil.

Serial dilution studies performed with RNA extracted from the PMTV-infested $S$. subterranea f. sp. subterranea sporosori and artificially spiked soil samples supported the reliability of these assays for the detection and quantification of PMTV. Both assays showed good reproducibility, as indicated by measurements of the coefficient of variation percentage. Results also indicated that both assays were able to detect very low concentrations of virus templates obtained from the low concentration of vector in the soil. However, the detection rate of RT-ddPCR was substantially higher than that of qRT-PCR, even though low amounts of the target were present in the sample. Additionally, the RT-ddPCR assay displayed a higher degree of linearity than qRT-PCR when a 10-fold dilution series of RNA extracted from the $S$. subterranea $\mathrm{f}$. sp. subterranea sporosori was evaluated. With increased specificity and similar sensitivity to that of qRT-PCR, the recently developed RT-ddPCR assay offers a number of advantages over qRT-PCR, especially for the estimation of copy numbers of targeted genes or the concentration of virus in the RNA sample. However, standard curves generated from the control sample require prior information regarding the copy number for qRT-PCR to estimate the quantity of the target in the sample; then, the assessment is based on the difference in relative copy number. Therefore, data generated are calculations that are highly dependent on the quality of standards used. Unfortunately, the development of a control sample with a known concentration of serial dilutions to use in a standard curve construction can be time-consuming, labor-intensive, and expensive (Kim et al. 2013). However, RT-ddPCR, as an endpoint PCR, does not need a standard curve and offers an absolute number of viral RNA copies present in the total RNA sample. Consequently, it appears more useful when prior information regarding the copy number of the control is not available and does not depend on PCR efficiency or require technical replicates. Another advantage that RT-ddPCR has over qRT-PCR is that it is known to be less susceptible to PCR inhibitors (Dingle et al. 2013; Rački et al.

TABLE 3. Detection of Potato mop top virus (PMTV) by quantitative reverse-transcription PCR (qRT-PCR) and reverse-transcription droplet digital PCR (RTddPCR) using total RNA extracted from the field-collected soil samples ${ }^{\text {a }}$

\begin{tabular}{|c|c|c|c|c|c|c|c|c|c|c|c|}
\hline $\begin{array}{l}\text { Sample } \\
\text { number }\end{array}$ & $\begin{array}{l}\text { Sample } \\
\text { ID }\end{array}$ & $\begin{array}{c}\text { State } \\
\text { obtained }\end{array}$ & $\begin{array}{l}\text { Soil } \\
\mathrm{pH}\end{array}$ & $\begin{array}{c}\text { Soil } \\
\text { OM (\%) }\end{array}$ & Soil texture & $\begin{array}{l}\text { Spongospora } \\
\text { subterranea } \\
\text { f. sp. subterranea } \\
\text { sporosori g-1 } \\
\text { of soil }\end{array}$ & $\begin{array}{c}\text { RT-PCR } \\
(\mathrm{Ct} \pm \mathrm{SD})\end{array}$ & $\mathrm{CV}(\%)$ & $\begin{array}{c}\text { RT-ddPCR } \\
\text { copies } \\
\mu \mathrm{l}^{-1}(\mathrm{Ct} \pm \mathrm{SD})\end{array}$ & CV (\%) & PMTV \\
\hline 1 & ME a1 & Maine & 5.4 & 5.1 & Silt loam & $4.1 \times 10^{4}$ & $29.88 \pm 0.25$ & 0.84 & $14.57 \pm 0.4$ & 2.77 & Positive \\
\hline 2 & $\mathrm{ME}$ a2 & Maine & 5.8 & 5.0 & Silt loam & $4.5 \times 10^{3}$ & $29.78 \pm 0.50$ & 1.68 & $13.13 \pm 1.50$ & 11.46 & Positive \\
\hline 3 & $\mathrm{ME} \mathrm{a} 3$ & Maine & 6.2 & 4.9 & Silt loam & $1.6 \times 10^{4}$ & $28.52 \pm 0.14$ & 0.49 & $54.53 \pm 2.81$ & 5.16 & Positive \\
\hline 4 & ME b1 & Maine & 5.8 & 5.0 & Silt loam & $1.7 \times 10^{3}$ & $30.04 \pm 0.59$ & 1.98 & $7.99 \pm 1.13$ & 14.08 & Positive \\
\hline 5 & ME b2 & Maine & 6.0 & 4.4 & Silt loam & $2.5 \times 10^{5}$ & $27.44 \pm 0.65$ & 2.36 & $75.73 \pm 3.91$ & 5.17 & Positive \\
\hline 6 & ME b3 & Maine & 6.2 & 4.9 & Silt loam & 0 & $-{ }^{\mathrm{b}}$ & - & - & - & Negative \\
\hline 7 & ID 1 & Idaho & 6.9 & 1.0 & Loamy sand & $4.02 \times 10^{5}$ & $29.80 \pm 0.69$ & 2.33 & $41.60 \pm 3.11$ & 7.48 & Positive \\
\hline 8 & ID 2 & Idaho & 6.6 & 1.2 & Loamy sand & $4.3 \times 10^{3}$ & $28.90 \pm 0.44$ & 1.54 & $43.67 \pm 4.19$ & 9.59 & Positive \\
\hline 9 & $\mathrm{CO} 1$ & Colorado & 7.5 & 1.4 & Loamy sand & $6.2 \times 10^{2}$ & $30.61 \pm 0.24$ & 0.80 & $6.00 \pm 0.37$ & 6.10 & Positive \\
\hline 10 & $\mathrm{CO} 2$ & Colorado & 7.2 & 1.1 & Loamy sand & 0 & - & - & - & - & Negative \\
\hline 11 & $\mathrm{CO} 3$ & Colorado & 7.6 & 1.3 & Loamy sand & $1.5 \times 10^{3}$ & $31.40 \pm 0.08$ & 0.25 & $6.28 \pm 0.74$ & 11.74 & Positive \\
\hline 12 & $\mathrm{CO} 4$ & Colorado & 7.6 & 1.4 & Loamy sand & $4.3 \times 10^{4}$ & $30.01 \pm 0.01$ & 0.05 & $22.20 \pm 3.54$ & 17.50 & Positive \\
\hline 13 & CO 5 & Colorado & 7.6 & 0.7 & Loamy sand & $5.6 \times 10^{4}$ & $30.46 \pm 0.20$ & 0.66 & $7.96 \pm 1.11$ & 13.93 & Positive \\
\hline 14 & ND 1 & North Dakota & 5.3 & 3.9 & Sandy loam & $3.7 \times 10^{5}$ & $26.74 \pm 0.48$ & 1.80 & $167.00 \pm 5.51$ & 3.28 & Positive \\
\hline 15 & ND 2 & North Dakota & 4.9 & 3.5 & Sandy loam & $1.1 \times 10^{6}$ & $27.45 \pm 0.69$ & 2.52 & $72.43 \pm 6.68$ & 9.22 & Positive \\
\hline 16 & ND 3 & North Dakota & 5.0 & 3.7 & Sandy loam & $1.2 \times 10^{6}$ & $28.36 \pm 0.51$ & 1.79 & $27.40 \pm 0.90$ & 3.28 & Positive \\
\hline 17 & ND 4 & North Dakota & 5.0 & 2.8 & Sandy loam & $1.5 \times 10^{5}$ & $28.11 \pm 0.75$ & 2.66 & $42.57 \pm 1.93$ & 4.55 & Positive \\
\hline 18 & ND 5 & North Dakota & 4.6 & 2.8 & Sandy loam & $1.7 \times 10^{3}$ & $29.90 \pm 0.99$ & 3.31 & $12.37 \pm 0.40$ & 3.27 & Positive \\
\hline 19 & ND 6 & North Dakota & 5.1 & 3.3 & Sandy loam & $1.3 \times 10^{2}$ & - & - & - & - & Negative \\
\hline 20 & WA a1 & Washington & 7.4 & 1.7 & Sand & $3.4 \times 10^{5}$ & $28.22 \pm 0.30$ & 1.06 & $55.30 \pm 5.07$ & 9.17 & Positive \\
\hline 21 & WA a2 & Washington & 7.5 & 1.6 & Sand & $5.1 \times 10^{5}$ & $28.93 \pm 0.20$ & 0.69 & $19.97 \pm 3.10$ & 15.52 & Positive \\
\hline 22 & WA b1 & Washington & 6.7 & 0.9 & Sand & $5.8 \times 10^{3}$ & $29.59 \pm 0.59$ & 1.98 & $14.93 \pm 2.11$ & 14.12 & Positive \\
\hline 23 & WA b2 & Washington & 6.8 & 0.9 & Sand & $1.45 \times 10^{5}$ & $28.12 \pm 0.24$ & 0.85 & $54.60 \pm 5.66$ & 10.36 & Positive \\
\hline 24 & WA b3 & Washington & 6.7 & 0.7 & Sand & $2.1 \times 10^{4}$ & $28.80 \pm 0.38$ & 1.33 & $33.03 \pm 2.62$ & 7.92 & Positive \\
\hline
\end{tabular}

${ }^{a} \mathrm{OM}$, Organic matter; $\mathrm{Ct}$, mean cycle threshold; $\mathrm{SD}$, standard deviation; and $\mathrm{CV}$, coefficient of variance.

b Dashes indicate not applicable. 
2014a), which could be beneficial when dealing with RNA samples extracted from soil. Such advantages of the RT-ddPCR approach over qRT-PCR for the detection of viruses have been reported in previous studies (Abachin et al. 2018; Rački et al. 2014b; Wu et al. 2017).

Results obtained from performing assays of spiked and naturally infested soils demonstrated that qRT-PCR and RT-ddPCR were in agreement and that both worked well for the detection of PMTV in soil-extracted RNA, demonstrating that both PCR methods can be used effectively. Yet, some qRT-PCR test results obtained from field-collected samples can be inconclusive, especially when $\mathrm{Ct}$ values are at the upper limit. Under these conditions, it is advantageous to use RT-ddPCR as an additional tool to confirm qRT-PCR results because of its sensitivity. In the serial dilution of RNA extracted from soil artificially spiked with PMTV-infested S. subterranea f. sp. subterranea sporosori, RT-ddPCR was able to detect as few as 0.22 PMTV copies $/ \mu l^{-1}$, thus demonstrating high sensitivity. However, such sensitivity is unlikely to be achieved when working with RNA extracted from the naturally infested soil. However, it is expected to produce useful information to differentiate between PMTV-positive and PMTV-negative soil samples, which will assist the potato industry in making disease management decisions.

Successful detection of PMTV from diverse samples showed the ability of the proposed method to detect PMTV from the wide variety of soil types. Because PMTV has been detected in the United States only fairly recently (Lambert et al. 2003), and because it continues to be detected in new potato production areas (Kaur et al. 2016), the detection method described here could be extremely beneficial for surveys used to determine the extent of this invasive virus.

Frequent unpredictable distributions of PMTV in its vector and vector in the field (Jones and Harrison 1972) could make accurate PMTV detection and verification of test results of field-collected soil samples challenging. If feasible, then it is advisable to test soil collected near potato tubers or soil that has adhered to tubers or separated from the tubers because these soils are expected to contain a higher concentration of $S$. subterranea $\mathrm{f}$. sp. subterranea resting spores (Sandgren 1995; Santala et al. 2010). Moreover, it is possible to prescreen the field for $S$. subterranea $\mathrm{f}$. sp. subterranea before deciding to test for PMTV. Further studies should be conducted to understand the dispersal of PMTV in the field and develop a reliable sampling method to maximize accurate PMTV detection.

In conclusion, soil assay methods developed in this study have been demonstrated to detect PMTV in a wide range of soils. These procedures provide rapidity, high sensitivity, high specificity, and the possibility of quantitative measurements. Now, for the first time, there is a reproducible direct assessment of the presence of PMTV in field soil that will facilitate further disease management options such as the planting of PMTV-insensitive cultivars (Domfeh et al. 2015; Yellareddygari et al. 2018) or the avoidance of planting the field with potato.

\section{ACKNOWLEDGMENTS}

We thank Dean Peterson and Francisco M. Bittara for their assistance.

\section{LITERATURE CITED}

Abachin, E., Convers, S., Falque, S., Esson, R., Mallet, L., and Nougarede, N. 2018. Comparison of reverse-transcriptase qPCR and droplet digital PCR for the quantification of dengue virus nucleic acid. Biologicals 52:49-54.

Abbas, A., and Madadi, M. 2016. A review paper on Potato mop-top virus (PMTV): Occurrence, properties and management. World J. Biol. Biotechnol. 1:129-134.

Adams, M. J., Antoniw, J. F., and Kreuze, J. 2009. Virgaviridae: A new family of rod-shaped plant viruses. Arch. Virol. 154:1967-1972.

Adams, M. J., Antoniw, J. F., and Mullins, J. G. L. 2001. Plant virus transmission by plasmodiophorid fungi is associated with distinctive transmembrane regions of virus-encoded proteins. Arch. Virol. 146:1139-1153.
Adams, M. J., Heinze, C., Jackson, A. O., Kreuze, J. F., Macfarlane, S. A., and Torrance, L. 2012. Family Virgaviridae. Pages 1139-1162 in: Virus Taxonomy: Classification and Nomenclature of Viruses-Ninth Report of the International Committee on Taxonomy of Viruses. A. M. Q. King, M. J. Adams, E. B. Carstens, and E. J. Lefkowitz, eds. Elsevier Academic Press, Waltham, MA.

Arif, M., Ali, M., Rehman, A., and Fahim, M. 2014. Detection of potato moptop virus in soils and potato tubers using bait plant bioassay, ELISA and RTPCR. J. Virol. Methods 195:221-227.

Arif, M., Torrance, L., and Reavy, B. 1995. Acquisition and transmission of potato mop-top furovirus by a culture of Spongospora subterranea $\mathrm{f}$. $\mathrm{sp}$. subterranea derived from a single cystosorus. Ann. Appl. Biol. 126: 493-503.

Beuch, U., Berlin, S., Åkerblom, J., Nicolaisen, M., Nielsen, S. L., Crosslin, J. M., Hamm, P. B., Santala, J., Valkonen, J. P. T., and Kvarnheden, A. 2015. Diversity and evolution of potato mop-top virus. Arch. Virol. 160: 1345-1351.

Bittara, F. G., Thompson, A. L., Gudmestad, N. C., and Secor, G. A. 2016. Field evaluation of potato genotypes for resistance to powdery scab on tubers and root gall formation caused by Spongospora subterranea. Am. J. Potato Res. 93:497-508.

Calvert, E. L. 1968. The reaction of potato varieties to potato mop-top virus. Rec. Agric. Res. Minist. Agric. North. Irel. 17:31-40.

Crosslin, J. M. 2011. First report of Potato mop-top virus on potatoes in Washington State. Plant Dis. 95:1483.

Davey, T. 2009. An accelerated soil bait assay for the detection of Potato mop top virus in agricultural soil. Pages 259-265 in: Plant Pathology: Techniques and Protocols. R. Burns, ed. Humana Press, New York.

David, N., Mallik, I., Crosslin, J. M., and Gudmestad, N. C. 2010. First report of Potato mop-top virus in North Dakota. Plant Dis. 94:1506.

Deb, M., and Anderson, J. M. 2008. Development of a multiplexed PCR detection method for Barley and Cereal yellow dwarf viruses, Wheat spindle streak virus, Wheat streak mosaic virus and Soil-borne wheat mosaic virus. J. Virol. Methods 148:17-24.

Dingle, T. C., Sedlak, R. H., Cook, L., and Jerome, K. R. 2013. Tolerance of droplet-digital PCR vs real-time quantitative PCR to inhibitory substances. Clin. Chem. 59:1670-1672.

Domfeh, O., Bittara, F. G., and Gudmestad, N. C. 2015. Sensitivity of potato cultivars to Potato mop-top virus-induced tuber necrosis. Plant Dis. 99: 788-796.

Falloon, R. E. 2008. Control of powdery scab of potato: Towards integrated disease management. Am. J. Potato Res. 85:253-260.

Garcia, B. N., Gutierrez, P. A., and Marın Montoya, M. 2013a. Deteccion y cuantificacion del Potato mop-top virus (PMTV) en Colombia mediante qRT-PCR. Acta Agron. 62:120-128.

Garcia, Y. G., Sanchez, P. A. G., and Montoya, M. M. 2013b. Detection of PMTV using polyclonal antibodies raised against a capsid-specific peptide antigen. Rev. Fac. Nal. Agr. Medellín 66:6999-7008.

Ghorbani, A., Izadpanah, K., Manzari, F., and Roumi, V. 2013. A simple method for detection of Polymyxa betae and Beet necrotic yellow vein virus in soil. J. Plant Pathol. 95:533-537.

Gil, J. F., Adams, I., Boonham, N., Nielsen, S. L., and Nicolaisen, M. 2016. Molecular and biological characterization of Potato mop-top virus (PMTV, Pomovirus) isolates from potato growing regions in Colombia. Plant Pathol. 65:1210-1220.

Jones, R. A. C., and Harrison, B. D. 1972. Ecological studies on potato moptop virus in Scotland. Ann. Appl. Biol. 71:47-57.

Kashiwazaki, S., Scott, K. P., Reavy, B., and Harrison, B. D. 1995. Sequence analysis and gene content of potato mop-top virus RNA 3: Further evidence of heterogeneity in the genome organization of furoviruses. Virology 206: 701-706.

Kaur, N., Cating, R. A., Dung, J. K. S., Frost, K. E., Robinson, B. A., and Hamm, P. B. 2016. First report of Potato mop-top virus infecting potato in Oregon. Plant Dis. 100:2337.

Kim, T. G., Yi, T., and Cho, K. S. 2013. Use of artificial DNA with multiple probe sites as reference DNA templates for quantitative real-time PCR to examine methanogen communities. J. Environ. Sci. Heal. 48:417-421.

Kirk, H. G. 2008. Mop-top virus, relationship to its vector. Am. J. Potato Res. $85: 261-265$.

Lambert, D. H., Levy, L., Mavrodieva, V. A., Johnson, S. B., Babcock, M. J., and Vayda, M. E. 2003. First report of Potato mop-top virus on potato from the United States. Plant Dis. 87:872.

Mallik, I., Fulladolsa, A. C., Yellareddygari, S. K. R., Francisco, G. B., Charkowski, A. O., and Gudmestad, N. C. 2019. Detection and quantification of Spongospora subterranea sporosori in soil by quantitative realtime PCR. Plant Dis.: PDIS-05-19-1092-RE.

Mallik, I., and Gudmestad, N. C. 2015. First report of Potato mop top virus causing potato tuber necrosis in Colorado and New Mexico. Plant Dis. 99: 164. 
Merz, U., and Falloon, R. E. 2009. Review: Powdery scab of potato-Increased knowledge of pathogen biology and disease epidemiology for effective disease management. Potato Res. 52:17-37.

Meunier, A., Schmit, J. F., Stas, A., Kutluk, N. and Bragard, C. 2003. Multiplex reverse transcription-PCR for simultaneous detection of Beet necrotic yellow vein virus, Beet soil borne virus, and Beet virus $Q$ and their vector Polymyxa betae KESKIN on sugar beet. Appl. Environ. Microbiol. 69: 2356-2360.

Mumford, R. A., Walsh, K., Barker, I., and Boonham, N. 2000. Detection of Potato mop top virus and Tobacco rattle virus using a multiplex real-time fluorescent reverse transcription polymerase chain reaction assay. Phytopathology 90:448-453.

Nakayama, T., Maoka, T., Hataya, T., Shimizu, M., Fuwa, H., Tsuda, S., and Mori, M. 2010. Diagnosis of Potato mop-top virus in soil using bait plant bioassay and RT-PCR-microplate hybridization. Am. J. Potato Res. 87: 218-225.

Rački, N., Dreo, T., Gutierrez-Aguirre, I., Blejec, A., and Ravnikar, M. 2014a. Reverse transcriptase droplet digital PCR shows high resilience to PCR inhibitors from plant, soil and water samples. Plant Methods 10:42.

Rački, N., Morisset, D., Gutierrez-Aguirre, I., and Ravnikar, M. 2014b. One step RT-droplet digital PCR: a breakthrough in the quantification of waterborne RNA viruses. Anal. Bioanal. Chem. 406:661-667.

Ramesh, S. V., Raikhy, G., Brown, C. R., Whitworth, J. L., and Pappu, H. R. 2014. Complete genomic characterization of a potato mop-top virus isolate from the United States. Arch. Virol. 159:3427-3433.

Ratti, C., Budge, G., Ward, L., Clover, G., Rubies-Autonell, C., and Henry, C. 2004. Detection and relative quantitation of Soil-borne cereal mosaic virus (SBCMV) and Polymyxa graminis in winter wheat using real-time PCR (TaqMan). J. Virol. Methods 122:95-103.

Reavy, B., Cowan, G. H., Arif, M., and Torrance, L. 1998. Association of sequences in the coat protein/readthrough domain of Potato mop-top virus with transmission by Spongospora subterranea. J. Gen. Virol. 79:2343-2347.

Ryazantsev, D. Y., and Zavriev, S. K. 2009. An efficient diagnostic method for the identification of potato viral pathogens. Mol. Biol. 43:515-523.

Sandgren, M. 1995. Potato mop-top virus (PMTV): Distribution in Sweden, development of symptoms during storage and cultivar trials in field and glasshouse. Potato Res. 38:379-389.
Sandgren, M., Plaisted, R. L., Watanabe, K. N., Olsson, S., and Valkonen, J. P. T. 2002. Evaluation of some North and South American potato breeding lines for resistance to Potato mop-top virus in Sweden. Am. J. Potato Res. 79:205-210.

Santala, J., Samuilova, O., Hannukkala, A., Latvala, S., Kortemaa, H., Beuch, U., Kvarnheden, A., Persson, P., Topp, K., Orstad, K., Spetz, C., Nielsen, S. L., Kirk, H. G., Budziszewska, M., Wieczorek, P., ObrepalskaSteplowska, A., Pospieszny, H., Kryszczuk, A., Sztangret-Wisniewska, J., Yin, Z., Chrzanowska, M., Zimnoch-Guzowska, E., Jackeviciene, E., Taluntyte, L., Pupola, N., Mihailova, J., Lielmane, I., Järvekulg, L., Kotkas, K., Rogozina, E., Sozonov, A., Tikhonovich, I., Horn, P., Broer, I., Kuusiene, S., Staniulis, J., Uth, J. G., Adam, G., and Valkonen, J. P. T. 2010. Detection, distribution and control of Potato mop-top virus, a soil-borne virus, in northern Europe. Ann. Appl. Biol. 157:163-178.

Savenkov, E. I., Germundsson, A., Zamyatnin, A. A., Jr., Sandgren, M. and Valkonen, J. P. T. 2003. Potato mop-top virus: The coat protein-encoding RNA and the gene for cysteine-rich protein are dispensable for systemic virus movement in Nicotiana benthamiana. J. Gen. Virol. 84:1001-1005.

Savenkov, E. I., Sandgren, M., and Valkonen, J. P. T. 1999. Complete sequence of RNA 1 and the presence of tRNA-like structure in all RNAs of Potato mop-top virus, genus Pomovirus. J. Gen. Virol. 80:2779-2784.

Scott, K. P., Kashiwazaki, S., Reavy, B., and Harrison, B. D. 1994. The nucleotide sequence of Potato mop-top virus RNA 2: A novel type of genome organization for a furovirus. J. Gen. Virol. 75:3561-3568.

Sokmen, M. A., Barker, H., and Torrance, L. 1998. Factors affecting the detection of potato mop-top virus in potato tubers and improvement of test procedures for more reliable assays. Ann. Appl. Biol. 133:55-63.

Wu, X., Lin, H., Chen, S., Xiao, L., Yang, M., An, W., Wang, Y., Yao, X., and Yang, Z. 2017. Development and application of a reverse transcriptase droplet digital PCR (RT-ddPCR) for sensitive and rapid detection of Japanese encephalitis virus. J. Virol. Methods 248:166-171.

Xu, H., DeHaan, T. L., and De Boer, S. H. 2004. Detection and confirmation of Potato mop-top virus in potatoes produced in the United States and Canada. Plant Dis. 88:363-367.

Yellareddygari, S. K. R., Whitworth, J. L., and Gudmestad, N. C. 2018. Assessing potato cultivar sensitivity to tuber necrosis caused by Potato mop-top virus. Plant Dis. 102:1148-1153. 